\title{
Pengembangan Instrumen Penilaian untuk Mengukur Motivasi Belajar Siswa SD
}

\author{
Ni Putu Aprilia Krismony ${ }^{1 *}$, Desak Putu Parmiti², I Gusti Ngurah Japa ${ }^{3}$ iD \\ ${ }^{123}$ Prodi Pendidikan Guru Sekolah Dasar, Universitas Pendidikan Ganesha, Singaraja, Indonesia \\ *Corresponding author: apriliakrismony@gmail.com
}

\section{Abstract}

Motivasi menjadi bagian penting dalam mendukung keberhasilan proses pembelajaran salah satunya adalah pembelajaran IPA. Namun pada kenyataanya alat untuk mengukur motivasi siswa keberadaanya masih sangat kurang. Tujuan dilaksanakannya penelitian ini adalah untuk mengembangkan instrumen penilaian motivasi belajar pada mata pelajaran IPA. Penelitian ini termasuk dalam penelitian pengembangan yang menggunakan model ADDIE dengan tahapan menganalisis, merancang, mengembangkan, mengimplementasikan dan mengevaluasi. Subjek dari penelitian ini yaitu instrumen penilaian motivasi belajar. Instrumen penilaian motivasi belajar IPA diuji oleh pakar. Metode pengumpulan data yang digunakan adalah metode kuesioner dengan menggunakan skala Likert. Berdasarkan hasil analisis, instrumen penilaian motivasi belajar IPA yang dikembangkan ini memiliki nilai validitas yang sangat baik, yaitu 0,85 . Sedangkan derajat reliabilitasnya tinggi, yaitu 0,80. Berdasarkan hasil tersebut dapat disimpulkan bahwa instrumen penilaian motivasi belajar IPA yang telah dikembangkan teruji valid dan reliabel, sehingga layak digunakan untuk mengukur motivasi belajar IPA. Implikasi penelitian ini adalah melalui instrumen motivasi yang dikembangkan ini, guru dapat menerapkannya dalam mengukur tingkat motivasi belajar siswa untuk dijadikan patokan dalam pengambilan tindakan selanjutnya.

Keywords: Instrumen, ADDIE, Motivasi Belajar IPA

\section{Abstract}

Motivation is an important part in supporting the success of the learning process, one of which is science learning. But in fact, the tools to measure student motivation are still lacking. The purpose of carrying out this research is to develop an instrument for assessing learning motivation in science subjects. This research is included in development research using the ADDIE model with the stages of analyzing, designing, developing, implementing and evaluating. The subject of this research is the learning motivation assessment instrument. The science learning motivation assessment instrument was tested by experts. The data collection method used was a questionnaire method using a Likert scale. Based on the results of the analysis, the developed science learning motivation assessment instrument has a very good validity value, namely 0.85 . While the degree of reliability is high, namely 0.80 . Based on these results, it can be concluded that the science learning motivation assessment instrument that has been developed has been tested valid and reliable, so it is suitable to be used to measure science learning motivation. The implication of this research is that through this developed motivation instrument, the teacher can apply it in measuring the level of student motivation to be used as a benchmark for further action.

Keywords: Instruments, ADDIE, Natural Science Motivation

\section{Introduction}

Muatan pembelajaran yang terdapat dalam pembelajaran tematik di SD salah satunya adalah Ilmu Pengetahuan Alam (IPA). Menurut Susanto (2013) IPA menjadi salah satu mata pelajaran pokok dalam kurikulum pendidikan di Indonesia, termasuk pada jenjang sekolah dasar. Ilmu pengetahuan alam merupakan pelajaran yang diterima dari jenjang pendidikan

$\begin{array}{lll}\text { History: } & \text { Publisher: Undiksha Press } \\ \text { Received } & \text { : } 5 \text { Juni } 2020 & \text { Licensed: This work is licensed under } \\ \text { Revised } & \text { : } 25 \text { Juni } 2020 & \text { a Creative Commons Attribution 3.0 License } \\ \text { Accepted } & : 6 \text { Juli } 2020 & \text { SO }\end{array}$


sekolah dasar sampai dengan pendidikan menengah atas (Ariyanto 2016). Purbosari (2016) menyatakan IPA dalam bahasa inggris disebut dengan Natural Science yang disingkat menjadi kata Science merupakan pengetahuan tentang alam dan segala isinya meliputi gejalagejala atau peristiwa-peristiwa di alam maupun kebendaan sekaligus cara atau metode untuk mengetahui dan memahami alam dan isinya. Menurut kelompok kerja dosen IPA PGSD (2018) Ilmu Pengetahuan Alam (IPA) merupakan ilmu pengetahuan yang mengkaji gejalagejala alam semesta, termasuk bumi ini sehingga terbentuk konsep dan prinsip. Tujuan pembelajaran IPA di sekolah dasar BSNP (dalam Susanto, 2013: 171), yaitu memperoleh keyakinan dan menumbuhkan rasa bersyukur atas kebesaran Tuhan Yang Maha Esa berdasarkan keindahahan alam yang diciptakannya, dapat mengembangkan pemahaman maupun pengetahuan mengenai konsep-konsep IPA yang bermanfaat dalam kehidupan sehari-hari, tumbuhnya rasa ingin tahu dan sikap positif terhadap adanya hubungan antara IPA lingkungan, teknologi, dan masyarakat, dapat meningkatkan kesadaran dari dalam sendiri untuk memelihara, menjaga, dan melestarikan alam sekitar, serta memperoleh bekal yang berguna mengenai pengetahuan, konsep, dan keterampilan IPA sebagai dasar untuk melanjutkan pendidikan ke jenjang yang lebih tinggi.

Namun faktanya ketercapaian tujuan pembelajaran IPA masih rendah. Hal ini terlihat dari hasil survei PISA tahun 2018 menunjukkan, rata-rata skor keterampilan sains siswa Indonesia masih dibawah rata-rata skor OECD, yaitu $396<489$ (Permana, 2019). Selain itu, hasil pencatatan dokumen tentang nilai ulangan tengah semester (UTS) IPA pada kelas V di SD Gugus II Majapahit Kecamatan Pekutatan dari 172 peserta didik, terdapat 54 peserta didik atau sama dengan $31,40 \%$ peserta didik yang belum mencapai KKM. Selanjutnya, berdasarkan hasil observasi ke dalam kelas ditemukan beberapa permasalahan, meliputi: 1) masih terdapat peserta didik yang terlihat tidak fokus dalam mengikuti pembelajaran IPA, 2) ketika guru mengajukan pertanyaan, hanya beberapa orang saja yang aktif menjawab sedangkan peserta didik yang lainnya hanya diam, 3) kurangnya antusias peserta didik ketika guru memberikan tugas kelompok dan peserta didik tidak sungguh-sungguh mengerjakan tugas yang diberikan, 4) kurangnya kemauan peserta didik untuk menyampaikan tugasnya di depan kelas, 5) guru memfokuskan pada penilaian kognitif peserta didik, yaitu mengukur memahaman dan pengetahuan siswa pada materi yang diajarkan, 6) guru belum melakukan penilaian pada aspek afektif peserta didik khususnya pada motivasi belajar IPA dengan menggunakan instrumen penilaian, sehingga permasalahan yang ditemukan di atas memperlihatkan bahwa motivasi belajar IPA siswa kelas V di SD Gugus II Majapahit Kecamatan Pekutatan belum optimal. Hasil observasi ini juga dikuatkan oleh pernyataan para guru kelas V SD Gugus II Majapahit Kecamatan Pekutatan yang menyatakan terdapat masalah, yaitu motivasi belajar peserta didik khususnya pada mata pelajaran IPA belum optimal dan belum adanya instrumen penilaian yang digunakan untuk mengukur motivasi belajar IPA. Merujuk pada temuan tersebut, maka dapat diidentifikasi salah satu penyebab rendahnya hasil belajar IPA siswa, yaitu belum optimalnya motivasi belajar siswa saat mengikuti proses pembelajaran IPA dan belum adanya instrumen penilaian yang dapat digunakan untuk mengukur motivasi belajar siswa. Jika temuan permasalahan tersebut tidak segera diatasi, tentu ketercapaian tujuan pembelajaran IPA tidak akan optimal dan hal ini berpengaruh pada kualitas pendidikan Indonesia, seperti yang tercermin dari hasil survei PISA tahun 2018 yang sudah dipaparkan di atas.

Alternatif solusi yang dapat diterapkan adalah dengan mengembangkan instrumen penilaian motivasi belajar siswa pada mata pelajaran IPA. Menurut Mudanta dkk (2020) untuk mendapatkan informasi yang berkaitan dengan kemampuan dan juga minat siswa dalam mengikuti pembelajaran diperlukan sebuah pendukung untuk mendatanya, yaitu menggunakan instrumen. Penilaian merupakan salah satu bagian penting dalam proses pembelajaran, maka perlu digunakan instrumen penilaian yang mampu menilai aspek 
kognitif, afektif, dan psikomotorik untuk mendapatkan hasil penilaian yang menyeluruh Pasaribu (2016). Hasil penelitian Yuniarto (2017) menujukan, adanya instrumen penilaian motivasi memberikan pengaruh positif terhadap peningkatan nilai kognitif mahasiswa. Instrumen yang akan digunakan untuk mengukur motivasi belajar siswa berupa kuesioner. Talitha \& Chendra (2018) menyatakan kuesioner merupakan suatu metode pengumpulan data yang dapat digunakan untuk mengukur motivasi belajar siswa, yaitu berupa daftar pertanyaan yang harus diisi atau dijawab oleh responden atau orang yang akan diukur. Dengan ini guru bisa melakukan penilaian pada aspek afektif peserta didik, karena sebagai seorang guru tidak cukup hanya mengukur pada aspek kognitif peserta didik, guru juga perlu mengukur aspek afektif seperti motivasi belajar siswa. Hal senada juga disampaikan Candra dkk (2018), yaitu penilaian yang dilakukan seorang guru tidak hanya berkaitan dengan kemampuan kognitif siswa, tetapi mencakup dua ranah lainnya yaitu ranah afektif (sikap) dan juga psychomotor (keterampilan).

Motivasi merupakan dorongan dari dalam diri untuk melakukan suatu hal agar tercapainya tujuan yang diinginkan. Motivasi menjadi peran yang sangat penting dalam proses pembelajaran, karena motivasi dapat menumbuhkan semangat dalam diri, tumbuhnya rasa ingin tahu dan aktif dalam pembelajaran, sehingga dengan adanya motivasi maka peserta didik dapat terdorong untuk belajar lebih serius. Menurut Sugeng (2016) motivasi belajar merupakan kondisi psikologis yang akan mendorong seseorang untuk melakukan sesuatu dan motivasi juga sebagai daya penggerak yang menimbulkan kegiatan belajar, sehingga tujuan belajar yang diharapkan akan tercapai. Ernata (2017) menyatakan bahwa motivasi merupakan suatu pendorong yang dapat mengubah energi dalam diri seseorang ke dalam bentuk aktivitas nyata dan dorongan untuk berusaha melakukan perubahan terhadap tingkah laku untuk menjadi yang lebih baik. Pendapat lain Brophy (dalam Koca, 2016) menyatakan bahwa motivasi belajar adalah kompetensi diperoleh melalui pemodelan, komunikasi harapan dan instruksi langsung atau sosialisasi oleh orang lain yang signifikan. Sedangkan Warti (2016) menyatakan bahwa motivasi merupakan kemauan, keinginan, kehendak yang muncul dari dalam masing-masing individu yang dapat mendorong seseorang untuk melakukan kegiatan. Jadi, motivasi merupakan energi berupa dorongan dalam diri seseorang yang dapat mengubah tingkah laku seseorang menjadi lebih baik sehingga adanya dorongan untuk melakukan kegiatan atau aktivitas nyata.

Dalam kegiatan belajar motivasi sangat diperlukan oleh peserta didik, sebab peserta didik yang tidak memiliki motivasi dalam belajar tentu tidak akan melakukan aktivitas belajar Masni (2017). Menurut Dimyati dan Mujiyono (dalam Nurmala dkk., 2014), motivasi sangat bermanfaat bagi siswa dan guru dalam proses pembelajaran, yaitu dengan adanya motivasi siswa akan bersemangat dan dapat belajar secara terarah, sedangkan guru memiliki peran untuk menumbuhkan serta menjaga motivasi siswa untuk terus belajar. Selanjutnya Suprihatin (2015) menyatakan keberhasilan dalam pembelajaran sangat dipengaruhi oleh motivasi siswa dalam belajar. Lebih lanjut, hasil penelitian Sunadi (2013) menyatakan peningkatan motivasi belajar siswa berbanding lurus dengan peningkatan hasil belajarnya. Hasil penelitian Ulfah dkk (2016) juga menyatakan, adanya hubungan yang erat antara motivasi peserta didik dengan hasil belajar peserta didik. Oleh karena itu, setiap guru harus dapat memahami perbedaan motivasi yang dimiliki pada masing-masing siswa.

Berdasarkan kondisi tersebut, maka dilakukan suatu penelitian pengembangan yang berjudul Pengembangan Instrumen Penilaian Motivasi Belajar IPA Siswa Kelas V di SD Gugus II Majapahit Kecamatan Pekutatan Tahun Pelajaran 2019/2020. Tujuan penelitian ini adalah untuk mengetahui validitas dan reliabilitas instrumen penilaian motivasi belajar pada mata pelajaran IPA siswa kelas V di SD. 


\section{Materials and Methods}

Penelitian ini dilakukan di SD Gugus II Majapahit Kecamatan Pekutatan dengan menggunakan rancangan penelitian pengembangan (research development). Jihan dkk (2019) menyatakan bahwa penelitian dan pengembangan (Research and Development) merupakan langkah-langkah yang ditempuh untuk mengembangkan suatu produk yang baru atau penyempurnaan produk yang sudah ada dan bisa dipertanggungjawabkan oleh peneliti yang mengembangkan, sedangkan Borg and Gall (dalam Suarno \& Sukirno, 2015) menyatakan bahwa penelitian pengembangan $(\mathrm{R} \& \mathrm{D})$ merupakan penelitian yang digunakan untuk menemukan suatu produk dengan desain yang baru dan mengikuti prosedur aplikasi metode penelitian dengan menggunakan uji coba lapangan, evaluasi, dan merevisi produk hingga memenuhi kriteria keefektifan, kualitas atau sesuai dengan standar yang ada. Pendapat lain Junia \& Rachmadyanti (2018) menyatakan penelitian dan pengembangan adalah suatu proses yang digunakan dalam pengembangan suatu produk yang baru dan mengukur keefektifan produk yang dikembangkan. Jadi, penelitian pengembangan merupakan mengembangkan suatu produk yang baru atau penyempurnaan produk yang sudah ada dengan mengikuti prosedur metode penelitian dan melakukan uji coba lapangan, evaluasi dan merevisi sehingga memenuhi kriteria dengan standar yang ada. Produk yang dikembangkan juga diuji keefektifan.

Pengembangan yang dilakukan dalam penelitian ini, yaitu mengembangkan instrumen penilaian motivasi belajar IPA siswa kelas V sekolah dasar. Model yang digunakan untuk mengembangkan produk dalam penelitian ini adalah model ADDIE. Tanjung \& Parsika, (2015) menyatakan bahwa ADDIE merupakan model instruksional berupa proses umum secara tradisional yang digunakan oleh perancang instruksional. Pendapat lain Hidayat dkk (2017) menyatakan bahwa model ADDIE merupakan model yang sangat sederhana dan tersusun secara terprogram dengan urutan kegiatan-kegiatan yang jelas. Widiana (2016) menyatakan bahwa ADDIE merupakan desain model pembelajaran yang berdasarkan pada pendekatan sistem efektif dan efisien serta hasil evaluasi dalam setiap fase bersifat interaktif dan dapat membawa pengembangan pembelajaran ke fase selanjutnya. Jadi, model ADDIE merupakan model sederhana dan dapat digunakan untuk mengembangkan berbagai macam produk. Model ADDIE dapat di jadinya desain model pembelajaran pada pendekatan sistem yang efektif dan efisien. Maka dari itu, prosedur pada penelitian ini mengacu pada model ADDIE yang tahapannya dibagi menjadi lima yaitu menganalisis (analyze), merancang (design), mengembangkan (development), mengimplementasikan (implementation), mengevaluasi (evaluation). Untuk mempermudah pemahaman tentang tahapan model ADDIE maka tahapan tersebut disajikan kedalam Gambar 1 sebagai berikut.

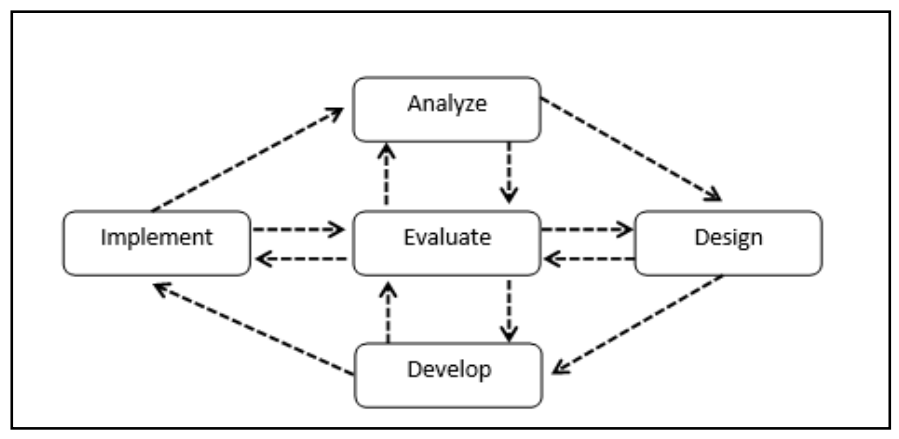

Gambar 1. Tahapan Model ADDIE

Data yang dikumpulkan pada penelitian ini adalah motivasi belajar siswa pada mata pelajaran IPA. Pengumpulan data pada penelitian pengembangan ini menggunakan metode 
kuesioner. Metode ini dilakukan dengan memberikan pernyataan atau pertanyaan tertulis untuk dijawab oleh responden. Instrumen motivasi belajar IPA yang dikembangkan sesuai dengan grand teori yang digunakan, yaitu mengacu pada aspek motivasi belajar yang dikembangkan berdasarkan teori Uno (2010). Sebelum membuat instrumen penilaian terlebih dahulu merumuskan indikator dan sub indikator motivasi belajar IPA yang telah ditentukan sebagaimana ditunjukkan pada Tabel 1.

Tabel 1. Indikator dan Sub Indikator Motivasi Belajar IPA

\begin{tabular}{|c|c|}
\hline Indikator Motivasi & Sub Indikator Motivasi \\
\hline $\begin{array}{l}\text { Adanya hasrat dan keinginan } \\
\text { berhasil }\end{array}$ & $\begin{array}{l}\text { 1. Aktif dalam belajar } \\
\text { 2. Senang dalam belajar } \\
\text { 3. Tidak cepat putus ada } \\
\text { 4. Tidak cepat puas dengan hasil yang didapatkan } \\
\text { 5. Ulet dalam menghadapi kesulitan belajar }\end{array}$ \\
\hline $\begin{array}{l}\text { Adanya dorongan dan kebutuhan } \\
\text { dalam belajar }\end{array}$ & $\begin{array}{l}\text { 1. Memiliki tujuan yang jelas dalam pembelajaran } \\
\text { 2. Rasa ingin tahu } \\
\text { 3. Adanya umpan balik } \\
\text { 4. Minat dalam belajar }\end{array}$ \\
\hline $\begin{array}{l}\text { Adanya harapan dan cita-cita } \\
\text { masa depan }\end{array}$ & $\begin{array}{l}\text { 1. Mencari hal-hal yang berhubungan dengan pembelajaran } \\
\text { 2. Ketekunan dalam belajar }\end{array}$ \\
\hline $\begin{array}{l}\text { Adanya kegiatan yang menarik } \\
\text { dalam belajar }\end{array}$ & $\begin{array}{l}\text { 1. Menghindari hukuman } \\
\text { 2. Pujian (penghargaan } \\
\text { 3. Mendapatkan prestasi di kelas } \\
\text { 4. Mendapatkan prestasi di kelas }\end{array}$ \\
\hline $\begin{array}{l}\text { Adanya lingkungan belajar yang } \\
\text { kondusif }\end{array}$ & $\begin{array}{l}\text { 1. Suasana tempat belajar } \\
\text { 2. Senang dengan cara guru mengajar di kelas }\end{array}$ \\
\hline
\end{tabular}

Pada Tabel 1 telah dirumuskan indikator dan sub indikator motivasi belajar IPA. Berdasarkan indikator dan sub indikator yang telah disusun, selanjutnya dirumuskan butirbutir pernyataan kuesioner yang ditunjukkan pada Tabel 2 .

Tabel 2. Rumusan Butir-butir Pernyataan Motivasi Belajar IPA

\begin{tabular}{|c|c|}
\hline Indikator & Butir Pernyataan \\
\hline Aktif dalam belajar & $\begin{array}{l}\text { - Saya mengikuti kegiatan pembelajaran dengan sungguh-sungguh } \\
\text { - Saya aktif bertanya pada saat proses pembelajaran } \\
\text { - Saya selalu berusaha mengerjakan tugas yang diberikan oleh guru dengan } \\
\text { benar } \\
\text { - Saya merasa bebas dan berani dalam mengemukakan pendapat selama proses } \\
\text { - } \text { - Saybelajaran berlangsung } \\
\text { - Saya tidak suka menanggapi pertanyaan yang diberikan oleh guru } \\
\text { - } \text { mengerti }\end{array}$ \\
\hline Senang dalam belajar & $\begin{array}{l}\text { - Secara umum, pembelajaran IPA sangat menyenangkan } \\
\text { - Saya senang ketika guru memberikan pujian kepada saya } \\
\text { - Saya suka bekerjasama dengan kelompok untuk menyelesaikan tugas yang } \\
\text { diberikan guru } \\
\text { - Pembelajaran IPA tidak menyenangkan bagi saya }\end{array}$ \\
\hline Tidak cepat putus asa & $\begin{array}{l}\text { - Saya tidak mudah menyerah saat mengalami kesulitan belajar IPA } \\
\text { - Saya mudah menyerah dan malas belajar ketika mendapatkan nilai yang jelek }\end{array}$ \\
\hline $\begin{array}{l}\text { Tidak cepat puas dengan } \\
\text { hasil yang didapatkan }\end{array}$ & - Saya akan belajar lebih giat lagi saat mendapatkan nilai yang memuaskan \\
\hline $\begin{array}{l}\text { Ulet dalam menghadapi } \\
\text { kesulitan belajar }\end{array}$ & $\begin{array}{l}\text { - Saya akan terus mempelajari berulang kali jika belum paham saat guru } \\
\text { menjelaskan }\end{array}$ \\
\hline Memiliki tujuan yang & n mempelajari materi pembelajaran IPA \\
\hline
\end{tabular}




\begin{tabular}{|c|c|}
\hline Indikator & Butir Pernyataan \\
\hline jelas dalam pembelajaran & \\
\hline Rasa ingin tahu & $\begin{array}{l}\text { - Saya senang mencari informasi yang berhubungan dengan pembelajaran IPA } \\
\text { dari sumber lain } \\
\text { - Saya senang mencari informasi yang berhubungan dngan pembelajaran IPA } \\
\text { dari sumber lain }\end{array}$ \\
\hline Adanya umpan balik & $\begin{array}{l}\text { - Saya tertarik dan merasa senang untuk menyelesaikan soal-soal IPA yang } \\
\text { diberikan guru } \\
\text { - Saya merasa keberatan apabila diberikan tugas rumah }\end{array}$ \\
\hline Minat dalam belajar & $\begin{array}{l}\text { - Saya selalu giat belajar dan mencari materi IPA dari sumber lain walaupun } \\
\text { tidak ada ujian }\end{array}$ \\
\hline $\begin{array}{l}\text { Mencari hal-hal yang } \\
\text { berhubungan dengan } \\
\text { pembelajaran }\end{array}$ & - $\quad$ Saya mengaitkan pembelajaran IPA dengan contoh nyata \\
\hline Ketekunan dalam belajar & - $\quad$ Saya tidak pernah merasa bosan dengan pembelajaran IPA \\
\hline Menghindari hukuman & $\begin{array}{l}\text { - Saya harus menyelesaikan tugas yang diberikan oleh guru agar tidak } \\
\text { mendapatkan hukuman }\end{array}$ \\
\hline Pujian (penghargaan) & - $\quad$ Saya senang diacungkan jempol ketika menjawab pertanyaan \\
\hline $\begin{array}{l}\text { Mendapatkan prestasi di } \\
\text { kelas }\end{array}$ & $\begin{array}{l}\text { - Saya belajar dengan giat agar dapat juara } \\
\text { - Saya selalu memperhatikan penjelasan guru agar nilai saya bagus }\end{array}$ \\
\hline Suasana tempat belajar & $\begin{array}{l}\text { - Ruang belajar di sekolah sangat nyaman sehingga saya bisa fokus dalam } \\
\text { belajar IPA }\end{array}$ \\
\hline $\begin{array}{l}\text { Senang dengan cara guru } \\
\text { mengajar di kelas }\end{array}$ & $\begin{array}{l}\text { - Saya merasa senang saat guru memberikan pembelajaran IPA } \\
\text { - Saya tidak memahami dengan baik penjelasan guru }\end{array}$ \\
\hline
\end{tabular}

Setelah instrumen tersebut jadi maka selanjutnya instrumen tersebut dianalisis dengan statistik deskriptif. Adapun bagian-bagian dari analisis deskriptif meliputi: uji validitas, uji reliabilitas. Supaya instrumen benar-benar layak untuk digunakan di sekolah dasar.

\section{Results and Discussion}

Penelitian yang digunakan adalah penelitian pengembangan (research development). Penelitian ini menilai instrumen motivasi belajar IPA SD kelas V. Penelitian pengembangan merupakan suatu proses untuk mengembangkan produk yang sudah ada maupun menghasilkan produk yang baru. Pengembangan produk dalam penelitian ini menggunakan model ADDIE. Pemilihan model ini didasari atas pertimbangan bahwa model ini bersifat sederhana dan dikembangkan secara sistematis dan berpijak pada landasan teoretis desain pembelajaran. Model ini terdiri atas lima tahapan, yaitu: menganalisis (analyse), merancang (design), mengembangkan (development), mengimplementasikan (implementation), mengevaluasi (evaluation). Data yang dikumpulkan pada penelitian ini adalah motivasi belajar siswa pada mata pelajaran IPA. Pengumpulan data pada penelitian pengembangan ini menggunakan metode kuesioner. Metode ini dilakukan dengan memberikan pernyataan atau pertanyaan tertulis untuk dijawab oleh responden. Instrumen yang disusun disesuaikan dengan indikator berdasarkan teori Uno (2010). Adapun indikator-indikator yang akan digunakan, yaitu adanya hasrat dan keinginan berhasil, adanya dorongan dan kebutuhan dalam belajar, adanya harapan dan cita-cita masa depan, adanya penghargaan dalam belajar, adanya kegiatan yang menarik dalam belajar, dan adanya lingkungan yang kondusif.

Setelah tersusunnya instrumen yang berjumlah 35 pertanyaan, selanjutnya dilakukan uji Validitas isi dengan dua orang ahli sebagai penilai. Hasil analisis menunjukkan bahwa 5 
butir pernyataan yang tidak valid/gugur dan total pernyataan yang valid sebanyak 30 butir pernyataan. Untuk analisis uji validitas dan reliabilitas dapat disajikan dalam Tabel 3.

Tabel 3. Hasil Analisis Validitas Isi dan Reliabilitas Instrumen Motivasi Belajar Siswa

\begin{tabular}{lcc}
\multicolumn{1}{c}{ Analisis } & Hasil & Kriteria \\
\hline Validitas isi & 0,85 & Sangat Tinggi \\
\hline Reliabilitas & 0.80 & Tinggi \\
\hline
\end{tabular}

Berdasarkan Tabel 3, menunjukkan validitas isi instrumen dengan rumus Gregory diperoleh hasil sebesar 0,85 dan berada pada kriteria sangat tinggi, sedangkan hasil uji reliabilitas dengan Alpha -Cronbach menunjukkan hasil 0,80 yang berada pada kriteria tinggi. Menurut Azwar (dalam Arissaryadin \& Arimbawaa, 2020) koefisien reliabilitas yang semakin mendekati 1, artinya reliabilitasnya juga semakin tinggi. Sebaliknya, koefisien yang semakin mendekati 0, artinya reliabilitasnya semakin rendah. Berdasarkan hal tersebut dapat dikatakan bahwa instrumen motivasi mempunyai nilai validitas dan reliabilitas yang sangat tinggi. Hayati \& Lailatussaadah (2016), data dikatakan semakin akurat bilamana nilai validitas dan reliabilitas instrumen nya juga semakin tinggi.

Instrumen penilaian motivasi belajar siswa pada mata pelajaran IPA yang telah dikembangkan teruji valid. Jadi, instrumen ini layak untuk dikembangkan karena instrumen penilaian merupakan suatu instrumen yang harus ada dalam proses pembelajaran. Dan instrumen penilaian motivasi belajar juga sebagai alat bantu yang digunakan untuk memperoleh segala informasi untuk mengetahui tingkatan siswa secara objektif. Gronlund (dalam Abdullah, 2015) menyatakan penilaian merupakan suatu hal yang dilakukan secara bertahap yang terdiri dari tahap pengumpulan, menganalisis, dan menerjemahkan informasi untuk mengetahui tingkatan pemahaman atau keterampilan dan motivasi yang dimiliki oleh siswa. Hal tersebut berkaitan dengan hasil penelitian dari Sudibyo dkk (2017) menyatakan bahwa instrumen motivasi belajar yang dikembangkan memiliki nilai keterbacaan baik dan validitas isi sangat baik. Selanjutnya, hasil penelitian dari Pratiwi \& Fasha (2015) menyatakan bahwa terdapat pengaruh yang positif terhadap sikap disiplin siswa melalui pengembangan instrumen penilaian HOTS berbasis kurikulum 2013 mata pelajaran Fisika materi besaran dan satuan. Lebih lanjut, hasil penelitian dari Abi Hamid (2016) yang menyatakan instrumen penilaian hasil belajar siswa berbasis TIK pada pembelajaran DLE yang dihasilkan teruji valid dan praktis, sehingga dapat digunakan sebagai alat evaluasi terhadap hasil belajar siswa yang akurat pada aspek kognitif. Berdasarkan penelitian terdahulu yang telah dipaparkan, terbukti bahwa pengembangan instrumen penilaian berpengaruh terhadap beberapa macam variabel.

\section{Conclusion}

Berdasarkan hasil penelitian dan pembahasan, dapat diambil simpulan bahwa penelitian ini memperoleh instrumen penilaian motivasi belajar IPA dengan hasil validitas isi kuesioner yang sangat tinggi dan hasil uji validitas butir menyatakan seluruh pernyataan kuesioner valid, serta hasil dari uji reabilitas tinggi. Jadi, instrumen penilaian motivasi belajar IPA yang telah dikembangkan teruji valid dan reliabel, sehingga layak digunakan untuk mengukur motivasi belajar IPA pada siswa kelas V sekolah dasar. Adapun beberapa saran yang dapat disampaikan berdasarkan hasil penelitian mengembangkan instrumen motivasi belajar untuk guru dapat menggunakan instrumen penelitian motivasi tidak hanya pada pembelajaran IPA, tetapi juga bisa digunakan pada pembelajaran lainnya untuk mengetahui 
motivasi belajar yang dimiliki oleh peserta didik, dan untuk kepala sekolah memfasilitasi guru untuk mengembangkan instrumen penilaian yang sejenis agar dapat memberikan konstribusi positif terhadap kemajuan sekolah sehingga dapat mendukung peningkatan kualitas proses dan hasil pembelajaran, dan kepada peneliti lain, penelitian ini dapat dijadikan sebagai literatur mengenai masalah-masalah pembelajaran, khususnya mengenai pengembangan instrumen penilaian motivasi belajar pada mata pelajaran IPA. Kepada peneliti lain juga dapat membuat penelitian yang sama dengan mengembangkan instrumen penilaian motivasi belajar pada mata pelajaran lainnya.

\section{References}

Abi Hamad, M. (2016). Pengembangan Instrumen Penilaian Hasil Belajar Siswa Berbasis TIK pada Pembelajaran Dasar Listrik Elektronika. VOLT: Jurnal Ilmiah Pendidikan Teknik Elektro, 1(1), 37-46.

Arissaryadin, A., \& Arimbawaa, P. (2020). Validitas Dan Reliabilitas Instrumen Efikasi Diri Petani. Prosiding Seminar Nasional Agribisnis, 149-154.

Ariyanto, M. (2016). Peningkatan Hasil Belajar IPA Materi Kenampakan Rupa Bumi Menggunakan Model Scramble. Profesi Pendidikan Dasar, 3(2), 134-140.

Candra, I., Sulistya, N., \& Prasetyo, T. (2018). Pengembangan Instrumen Sikap Sosial Tematik Siswa SD Kelas IV. Jurnal Ilmiah Sekolah Dasar, 2(1), 455-461.

Ernata, Y. (2017). Analisis motivasi belajar peserta didik melalui pemberian reward dan punishment d isdn ngaringan $05 \mathrm{kec}$. Gandusari kab. Blitar. Jurnal Pemikiran Dan Pengembangan Sekolah Dasar (JP2SD), 5(2), 781-790.

Hidayat, H., Hartono, H., \& Sukiman, S. (2017). Pengembangan Learning Management System (LMS) untuk Bahasa Pemrograman PHP. Jurnal Ilmiah Core IT: Community Research Information Technology, 5(1), 20-29.

Jihan, A. N. F., Reffiane, F., \& Arisyanto, P. (2019). Pengembangan Media Ludo Raksasa Pada Tema Selalu Berhemat Energi Untuk Meningkatkan Motivasi Belajar Sswa Kelas IV Sekolah Dasar. Mimbar PGSD Undiksha, 7(2), 107-113.

Junia, U. C. H. A., \& Rachmadyanti, P. (2018). Pengembangan Media Mimbar (Domino Bergambar) Materi Keragaman Sosial, Ekonomi, Budaya, Etnis, dan Agama di Indonesia. Jurnal Penelitian Pendidikan Guru Sekolah Dasar, 6(3), 353-362.

Koca, F. (2016). Motivation to learn and Teacher-Student Relationship. Journal of International Education and Leadership, 6(2), 1-20.

Masni, H. (2017). Strategi Meningkatkan Motivasi Belajar Mahasiswa. Jurnal Ilmiah Dikdaya, 5(1), 34-45.

Mudanta, K. A., Astawan, I. G., \& Jayanta, I. N. L. (2020). Instrumen Penilaian Motivasi Belajar dan Hasil Belajar IPA Siswa Kelas V Sekolah Dasar. Mimbar Ilmu, 25(2), 101109.

Nurmala, D. A., Tripalupi, L. E., \& Suharsono, N. (2014). Pengaruh motivasi belajar dan aktivitas belajar terhadap hasil belajar akuntansi. Jurnal Pendidikan Ekonomi Undiksha, 4(1).

Pasaribu, A. (2016). Pengembangan Instrumen Autentik Assesmen Berupa Penilaian Proyek dengan Produk Mind Mapping pada Materi Gaya dan Hukum Newton Tentang Gerak. Jurnal Inovasi dan Pembelajaran Fisika, 3(2). 1-5. 
Permana, R. H. (2019). Survei Kualitas Pendidikan PISA 2018: RI Sepuluh Besar dari Bawah. https://news.detik.com/berita/d-4808456/survei-kualitas-pendidikan-pisa-2018ri-sepuluh-besar-dari-bawah

PGSD, K. K. D. I. (2018). Pendidikan IPA. Jurusan Pendidikan Guru Sekolah Dasar, Fakultas Ilmu Pendidikan, Universitas Pendidikan Ganesha.

Pratiwi, U., \& Fasha, E. F. (2015). Pengembangan Instrumen Penilaian HOTS Berbasis Kurikulum 2013 Terhadap Sikap Disiplin. Jurnal Penelitian Dan Pembelajaran IPA, 1(1), 123-142.

Purbosari, P. M. (2016). Pembelajaran berbasis proyek membuat ensiklopedia Ilmu Pengetahuan Alam (IPA) untuk meningkatkan academic skull pada mahasiswa. Scholaria: Jurnal Pendidikan dan Kebudayaan, 6(3), 231-238.

Suarno, D. T., \& Sukirno, S. (2015). Pengembangan Media Pembelajaran IPS Dengan Tema Pemanfaatan Dan Pelestarian Sungai Untuk Siswa Kelas VII SMP. Harmoni Sosial: Jurnal Pendidikan IPS, 2(2), 115-125.

Sudibyo, E., Jatmiko, B., \& Widodo, W. (2017). Pengembangan Instrumen Motivasi Belajar Fisika:Angket. Jurnal Penelitian Pendidikan IPA, 1(1), 13-21.

Sugeng, H. (2016). Pengaruh Kedisiplinan Siswa dan Motivasi Belajar Terhadap Prestasi Belajar Siswa Pada Mata Pelajaran Ekonomi di SMA Swasta Depok. Faktor Jurnal Ilmiah Kependidikan, 3(3), 261-274

Sunadi, L. (2013). Pengaruh motivasi belajar dan pemanfaatan fasilitas belajar terhadap prestasi belajar siswa pada mata pelajaran ekonomi kelas XI IPS di SMA Muhammadiyah 2 Surabaya. Jurnal Pendidikan Ekonomi (JUPE), 1(3).

Suprihatin, S. (2015). Upaya Guru dalam Meningkatkan Motivasi Belajar Siswa. Jurnal Pendidikan Ekonomi UM Metro, 3(1), 73-78.

Susanto, A. (2013). Teori Belajar dan Pembelajaran di Sekolah Dasar. Pranamedia Group.

Talitha Fendya, W., \& Chendra Wibawa, S. E. T. Y. A. (2018). Pengembangan Sistem Kuesioner Daring Dengan Metode Weight Product Untuk Mengetahui Kepuasan Pendidikan Komputer Pada LPK CYBER COMPUTER. IT-Edu: Jurnal Information Technology and Education, 3(01), 45-53.

Tanjung, M. R., \& Parsika, T. F. (2015). Pengembangan Aplikasi Multimedia Pengenalan dan Pembelajaran Origami dengan Pendekatan ADDIE. In Seminar Nasional Informatika, 1(1), 128-133.

Ulfah, K. R., Santoso, A., \& Utaya. (2016). Hubungan motivasi dengan hasil belajar IPS. Jurnal Pendidikan: Teori, Penelitian, Dan Pengembangan, 1(8), 1607-1611.

Uno, B. H. (2010). Teori Motivasi \& Pengukurannya. PT Bumi Aksara.

Warti, E. (2016). Pengaruh Motivasi Belajar Siswa terhadap Hasil Belajar Matematika Sisa di SD Angkasa 10 Halim Perdana Kusuma Jakarta Timur. Mosharafa: Jurnal Pendidikan Matematika, 5(2), 177-185.

Widiana, I. W. (2016). Pengembangan Assesmen Proyek dalam Pembelajaran IPA di Sekolah Dasar. Jurnal Pendidikan Indonesia, 5(2), 147-157.

Yuniarto, E. (2017). Pengembangan Instrumen Penilaian Motivasi Belajar Mahasiswa Pendidikan Matematika. Likhitaprajna, 19(2), 1-8. 
